\section{FRACTURE OF THE SKULL IN CHILDHOOD*}

JOHN T. MORRISON, O.B.E., F.R.C.S.

HONORARY SURGEON, ROYAL SOLTHERN HOSPITAL ; HONORARY ASSISTANT SURGEON, ROYAL LIVERPOOL CHILDREN'S HOSPITAL

$A N D$

MIRIAM ROSKIN, M.B., Сн.B.

CASUALTY OFFICER, ROYAL LIVERPOOL CHILDREN'S HOSPITAL

Children are so often in trouble as the combined result of youthful spirits, naughtiness, and inexperience, that a knowledge of the consequences of their everyday injuries should be the subject of careful inquiry. In the matter of head injuries the opportunity has occurred of studying a series at the Royal Liverpool Children's Hospital. The findings are of interest, not only from the academic point of view, but also from that of the general practitioner in his daily round, and in certain medico-legal aspects. We have not tried to deal with the subject in any exhaustive or systematic fashion, but have dwelt, as fully as the material at our disposal seemed to justify, upon those points which are not in accordance with accepted teaching, or upon which opinion has not yet crystallized. In many instances the statements in the literature are exceedingly confusing and often contradictory.

\section{Frequency of Fractured Skull}

The period covered by the present survey is approximately two years. During this time fifty-seven cases of fractured skull have been admitted to the City Branch of the Children's Hospital. In a corresponding period at the Royal Southern Hospital, with roughly twice as many beds, only twenty-five adult cases were dealt with. Further, in the course of the same two years the city coroner (Dr. G. Cecil Mort, whom we have to thank for his courtesy and assistance) held inquests on thirty-nine children under 12 in whom death was caused by fracture of the skull. Of this series our own ten fatal cases no doubt form part. It would appear that the elasticity of the growing bone, which is credited with saving so many youngsters from serious injury, is by no means so adequate a safeguard as has been supposed. At any rate the cases in which it has failed to protect the childoften a very young child-from fracture of the skull are not uncommon at a busy children's hospital. The youngest in this series was only 1 month old. Obstetrical fractures have not been included.

\section{Fractures of the Base}

In the past it has been accepted that " basal fractures are unusual in children." ${ }_{1}$ Kirmisson ${ }^{2}$ says: "In children we very rarely see fractures of the petrous part of the temporal bone and symptomatic bleeding from the ear." Very possibly these injuries are increasing in number with the growing frequency of motor accidents. In this series there are no fewer than twenty-two (38.6 per cent.) in whom the diagnosis of "fractured base" was made either upon the evidence of the escape of blood or cerebrospinal fluid from mouth, nose, or ears, or from $x$-ray examination. In the hands of competent observers these grounds are adequate. Radiography, although of the greatest assistance, gave positive findings in sixteen cases only. In two the report was " doubtful." In four it was " negative," but in one of these the presence of a basal fracture was definitely proved post mortem.

* A paper read before a meeting of the Denbigh and Flint Division of the British Medical Association.

\section{Causes of Fractured Skull}

It is regrettable, though hardly to be wondered at, that twenty-four out of the fifty-seven cases were the result of injuries by motor vehicles, while out of the fatal cases investigated by the coroner 87 per cent. were due to the same type of trauma. The causes of the remainder make motley reading. Sometimes the children arrive at hospital grossly shocked and bleeding from mouth or ears. Sometimes they are only brought up some days later with vague complaints or with a local bruise or haematoma. Without $x$-ray evidence no one would dare diagnose the extensive fractures that are sometimes found. Relatively slight injuries are capable of giving rise to fractures of the skull in childhood. In one case no history of trauma could be elicited. The following table reveals the very serious results that sometimes follow what appear to be minor accidents. Of necessity the term "relatively slight" is an elastic one, but it is obvious that in many. instances the injuries are only such as are not uncommon in ordinary households.

\begin{tabular}{|c|c|c|c|c|c|}
\hline $\begin{array}{c}\text { No. } \\
\text { of } \\
\text { Case }\end{array}$ & Age & $\begin{array}{l}\text { Nature of } \\
\text { Accident }\end{array}$ & $\begin{array}{l}\text { Symptoms } \\
\text { on } \\
\text { Admission }\end{array}$ & Local Signs & $\underset{\text { Report }}{X \text {-ray }}$ \\
\hline 5 & $3 \mathrm{mo}$. & $\begin{array}{l}\text { Mother fell with } \\
\text { baby against } \\
\text { bedpost }\end{array}$ & Nil & $\begin{array}{c}\text { Depression } \\
\text { palpable }\end{array}$ & No $x$ ray \\
\hline 18 & 11 jrs. & $\begin{array}{l}\text { Fell down "a } \\
\text { few" steps }\end{array}$ & $\begin{array}{c}\text { Dazed, } \\
\text { headache. }\end{array}$ & $\underset{\text { ear }}{\text { Bleeding from }}$ & $\begin{array}{l}\text { Fracture, } \\
\text { occipital. }\end{array}$ \\
\hline 22 & 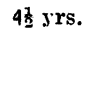 & $\begin{array}{cc}\text { Fell off } & \text { table } \\
\text { some } & \text { days } \\
\text { before } & \text { ad- } \\
\text { mission } & \end{array}$ & Headache & Oedema & $\begin{array}{l}\text { Crack, } \\
\text { occipital }\end{array}$ \\
\hline 31 & 7 mo. & $\begin{array}{l}\text { Fell down five or } \\
\text { six stops }\end{array}$ & Nil & $\begin{array}{l}\text { Slight bleeding, } \\
\text { nose; oedema } \\
\text { over eyes }\end{array}$ & $\begin{array}{l}\text { No } x \text { ray } \\
\text { P.M. } \\
\text { fractured }\end{array}$ \\
\hline 40 & $13 \mathrm{mo}$. & $\begin{array}{l}\text { Fe!l out of pram } \\
\text { some days } \\
\text { before ad- } \\
\text { mission }\end{array}$ & Nil & Ilaematoma & $\begin{array}{l}\text { Crack, } \\
\text { parietal }\end{array}$ \\
\hline 41 & $\begin{array}{c}6 \mathrm{yrs} \\
y\end{array}$ & $\begin{array}{l}\text { Fell off } 6 \mathrm{ft} \text {. wall } \\
\text { day before ad- } \\
\text { mission }\end{array}$ & $\begin{array}{c}\text { Two hours } \\
\text { uncon- } \\
\text { scious : } \\
\text { vom ted; } \\
\text { headache. }\end{array}$ & Tenderness & $\begin{array}{c}\text { Crack, } \\
\text { occipital }\end{array}$ \\
\hline 42 & $6 \mathrm{yrs}$. & $\underset{\substack{\text { No history } \\
\text { trauma }}}{ }$ & $\begin{array}{c}\text { Headache, } \\
\text { drowsy ; } \\
\text { yomiting }\end{array}$ & Haematoma & $\begin{array}{c}\text { Fracture, } \\
\text { parietal }\end{array}$ \\
\hline 47 & 11 yrs. & $\begin{array}{l}\text { Ran into tight } \\
\text { rope and fell } \\
\text { back }\end{array}$ & $\begin{array}{l}\text { Somining. } \\
\text { Shock }\end{array}$ & Nil & $\begin{array}{l}\text { Crack, } \\
\text { parietal }\end{array}$ \\
\hline 48 & $7 \mathrm{mo.}$ & $\begin{array}{l}\text { Mother fell with } \\
\text { baby }\end{array}$ & Nil & $\begin{array}{c}\text { Oedema and } \\
\text { tenderness }\end{array}$ & $\begin{array}{c}\text { Very } \\
\text { extensive }\end{array}$ \\
\hline 50 & 6 yrs. & $\begin{array}{l}\text { Fell down some } \\
\text { steps }\end{array}$ & $\begin{array}{l}\text { Very } \\
\text { drowsy }\end{array}$ & & $\begin{array}{l}\text { Fracture, } \\
\text { occipital. }\end{array}$ \\
\hline 51 & $1 \mathrm{mo}$. & Fell off bed & Nil & Haematoma & $\begin{array}{l}\text { Extensive } \\
\text { fracture. }\end{array}$ \\
\hline 52 & $17 \mathrm{mo}$. & $\begin{array}{l}\text { Fell, and mother } \\
\text { fell over him, } \\
\text { two days before } \\
\text { admission }\end{array}$ & Nil & Haematoma & Fracture, \\
\hline 53 & $7 \mathrm{jrs}$. & Fell off a wall & Nil & $\begin{array}{c}\text { Swelling, fore- } \\
\text { head; sub- } \\
\text { conjunctival } \\
\text { haeniorrhage }\end{array}$ & $\begin{array}{l}\text { Crack, } \\
\text { frontal }\end{array}$ \\
\hline 57 & - & $\begin{array}{l}\text { Knocked down by } \\
\text { bicycle three } \\
\text { days before ad- } \\
\text { mission }\end{array}$ & $\begin{array}{l}\text { Persistent } \\
\text { vomiting }\end{array}$ & $\begin{array}{l}\text { Nil } \\
\text { Nil }\end{array}$ & $\begin{array}{l}\text { Linear } \\
\text { fracture }\end{array}$ \\
\hline
\end{tabular}

\section{- Chief Symptoms and Signs}

The cardinal symptoms in these cases are threenamely :

1. Vomiting.

2. Impairment of consciousness.

3. Bleeding from mouth, nose, or ears. In a few, cerebro-spinal fluid was also found to be escaping.

Vomiting occurred in practically three-quarters of the cases (77 per cent.). It was sometimes very persistent. In a few instances it was only after the lapse of a day or two that it began to be troublesome. Where fracture of the skull was absent, but where concussion or unexplained shock suggested the possibility of that diagnosis, 
the percentage of cases with vomiting was appreciably lower-namely, 48 per cent. instead of 77 per cent.

Second in point of frequency comes impairment of consciousness; it was recorded in 66 per cent. of our fracture cases. During the same period seventy-four patients were admitted suffering from this symptom in whom no fracture was found. In other words, out of 112 patients suffering from some degree of impairment of consciousness about one-third (33.9 per cent.) proved to have fractures of the skull. The symptom varied from a transient dazed state to deep coma. It probably occurs much more frequently than is reported, because many of the patients are babies or young children, in whom minor manifestations of this condition are not appreciated by the lay observers present at the time of the accident. In 71 per cent. of fracture cases showing impairment of consciousness there was associated vorniting or else bleeding from mouth, nose, or ears to help to confirm the diagnosis.

There remain nineteen cases in which no impairment of consciousness was actually recorded. The leading signs and symptoms in these nineteen may be tabulated as follows :

Vomiting and bleeding from mouth, nose, or ears ... 8

Vomiting and local signs of injury to head $\ldots \quad \ldots \quad \ldots$

$\begin{array}{lllll}\text { Palpable depression of the skull } \ldots & \ldots & \ldots & \ldots & 2\end{array}$

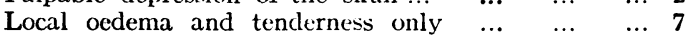

It will be seen, then, that in the majority of cases (fifty out of fifty-seven), the history of trauma involving or possibly involving the head'being given, where fracture of the skull has occurred, symptoms are present which in the light of the present investigation are strongly suggestive, if not diagnostic, of that lesion. In association with one or more of the three cardinal symptoms, local signs are of the greatest significance.

\section{Mortality}

The general mortality in the fifty-seven cases was nearly 18 per cent., but when the twenty-two cases of basal fracture are considered by themselves it is found that the death rate leaps up to the very grave proportion of one in three (32 per cent.). The immediate cause of death is set out in the following table:

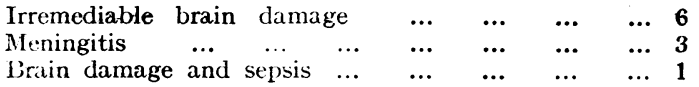

Of the first group the average stay in hospital before death was a matter of a few hours only, and such cases must be regarded as hopeless on account of the severity of the primary injury. The meningitis cases are those in which a fracture of the base was followed by an infection from the nasopharynx or the associated air passages, and a generalized spread to the meninges. The organism recovered by lumbar puncture was the pneumococcus in all cases, complicated in one individual by the presence of a streptococcus. In one of the pneumococcal cases there was a scarlatiniform rash thirty-six hours after the accident. It is possible, of course, that this was a pure coincidence, and that the child had been on the point of developing scarlet fever when the injury occurred. The trauma was relatively slight, and it was noted on admission that the child appeared lively and well. In one or two such cases of pneumococcal meningitis following unsuspected basal fracture we have seen recovery take place, but not within the present series. In the meningitis cases death occurred on the third, fourth, and ninth days respectively. No instance was seen of the late formation of an intracranial abscess. The patient whose death was attributed to brain damage and sepsis was very grossly injured. There was laceration of the dura and ultimately a hernia cerebri. He did not come directly under our control, and no primary operation was done. It is very doubtful, however, whether in any case he would have survived.

\section{Treatment}

All cases of head injury should be regarded as possible cases of fracture of the skull. The suspicion should also arise in children seen suffering from shock not otherwise adequately explained. During the period under review 181 such cases have been admitted, and of these, fifty-seven -that is, more than 31 per cent.-were found to have bone damage to the skull. It has been our practice to keep these fracture patients recumbent for ten days to a fortnight, and to advise mental quiet and physical rest for a further week, even in the milder cases. In all cases of fracture of the base of the skull our findings would suggest the advisability of a dose of antipneumococcal serum-and possibly antistreptococcal serum also-as early as may be after the injury.

Where an open wound exists early operation is imperative after treatment has successfully coped with the primary shock. Local anaesthesia is the method of choice, even in small children. Operation was performed in four cases. In three there was a compound fracture of the vault with depression of fragments; in one a large depression without open wound. Our methods are as follows: after infiltration of the subcutaneous tissues right down to the pericranium with $1 / 2$ per cent. novocain and 1 in 1,000 adrenaline ( $m$ viii ad $\xi j$ ), the edges of the wound are excised down to bone. The exposed bone is then painted with iodine. A small trephine may now be necessary, but in most cases it is possible to nibble away with fine gouge forceps an overhanging edge till access is gained to the under surface of the depressed fragment, which can then be elevated. Even fragments completely separated may be preserved. They contribute materially later on to the soundness of the skull. In no case in this small group did such fragments interfere with primary healing.' In all four, convalescence was uninterrupted and recovery complete. Drainage was not requircd. In one case transferred from another institution it was found that a scalp wound over a small depressed fracturc had been sutured without any operative cleansing. It was grossly infected, and the child was dangerously ill. The wound was opened up and antistreptococcal serum given, fortunately with excellent results. For those cases where a small depression exists, perhaps as large as the tip of the little finger, operation has not been considered necessary in the absence of an external wound. It is the routine practice to elevate the head of the bed, and when symptoms of increasing intracranial pressure ensue in the shape of slowing pulse and increasing drowsiness, attempts are made to counteract them by rectal injections of 10 per cent. salt solution. If this fails pressure is relieved by lumbar puncture, repeated if necessary. It is appreciated by us that the effect of this is only temporary, but we believe that extensive operations designed to give more permanent relief are not justifiable.*

\section{Prognosis}

This question is naturally of the greatest importance, quite apart from its increasing significance from a medicolegal point of view. In many quarters it is taken for granted that the chances of unpleasant sequels after head injuries in children are very small. In others the prospects of grave mental defects and epilepsy are altogether unduly stressed. A careful "follow-up" of our patients has shown that in approximately 50 per cent. of

* In the thirteen consecutive cases treated since the writing of this paper no single death has occurred. Included in this number have been four fractures of the base and three depressed fractureg of the vault, two of the latter bcing compound. 
the thirty-three whom we have been able to trace there have been departures from normal ; thirteen were stated to suffer from headaches, and of these, four also showed signs of increased nervousness in the shape of twitching, starting when spoken to, or speech defects. One was described as " very excitable." In one case the child's behaviour was found to have deteriorated, and one was said to be less intelligent. Two children suffered from unilateral facial paralysis following the accident, but in both cases recovery took place, in one completely in two months, but in the other slight drooping of the eyelid remained after nine months. In two some deafness occurred.

In an admirable paper devoted to this subject Beckman tells us that all such patients recover within two years, with the exception of perhaps 5 per cent. Nevertheless the unexpectedly high percentage of unpleasant sequels emphasizes the importance of prolonged rest. Beckman makes no reference to the development of epilepsy, and apart from convulsions noted shortly after the infliction of grave brain injury, and usually speedily fatal, we have seen no evidence in children of this complication. It must occur very rarely.

\section{Conclusions}

1. Fracture of the skull occurs in childhood much more frequently than is supposed.

2. It often results from apparently trivial injuries.

3. Fracture of the base is not uncommon, and is of very grave significance.

4. Sepsis must be forestalled by operative cleansing in compound fractures of the vault and by the prophylactic use of serum in fractures of the base.

5. Medical measures should be taken to prevent undue increase of intracranial pressure.

6. In view of the proportion of sequels prolonged rest is indicated.

REFERENCES

${ }^{1}$ Fraser: Surgery of Childhood, i, 510

${ }^{2}$ Kirmisson: Handbook of the Surgery of Children, p. 331.

${ }^{3}$ Beckman: Annals of Surgery, ixxxvii, 355

\section{A SWIFT AND SIMPLE METHOD FOR DECIDING PNEUMOCOCCAL "TYPE"}

BY

RICHARD R. ARMSTRONG, M.D., F.R.C.P.

(From the Research Laboratory, St. Bartholomew's Hospital)

Increasing attention has been paid during the past year to the treatment of lobar pneumonia by concentrated antipneumococcal serums. ${ }^{1}$ The serum available from American sources (Parke, Davis and Co., and Lederle) is divalent and effective against the pneumococcal Types I and II. A supply of Type I antiserum will probably soon become generally available from the Wellcome Research Laboratories. I am at present engaged on the treatment of selected severe cases of lobar pneumonia with each of these serums.

While there is some $\cdot$ doubt about the usefulness of Type II serum, there is good reason to consider the Type I serum of real therapeutic value. In these circumstances, the determination of the type of pneumococcus responsible for a given case of lobar pneumonia becomes a matter of urgency, first in the interests of the patient and, secondly, to avoid waste of the very costly serum.

A swift and simple method for deciding pneumococcal type is as follows. Type may be ascertained within four hours from the time of collecting sputum, or lung puncture fluid when sputum is not immediately available; other pathological material containing virulent pneumococci may, likewise, be used.

A suitable sample of sputum is chosen and emulsified in a watch-glass with an equal volume of broth. Half a cubic centimetre of the emulsion is inoculated into the peritoneal cavity of a mouse. Four hours later the peritoneal contents are sampled by aspiration in the following manner. The mouse is grasped by the scruff between the finger and thumb of the left hand; at the same time the animal's tail is firmly held against the inner side of the palm of the hand by the third and fourth fingers. The abdomen is thus conveniently exposed and explored by means of a $1 \mathrm{c.cm}$. Record syringe with fine No. 18 rustless steel needle attached. The barrel of the syringe should be held by the third and fourth fingers of the right hand against the palm, and the plunger lifted by the right thumb and index.

Four droplets of the peritoneal exudate thus obtained are expressed on to slides, appropriately marked with grease pencil to correspond with the three chief pneumococcal types and control ; the droplets are at once mixed with a platinum loopful of Types I, II, and III agglutinating serums and rabbits' normal serum. The drops are covered with cover-slips as soon as mixed, and examined at once under the microscope, using a No. 4 ocular $1 / 6$ inch objective with plane mirror reflector, the condensor being removed. Focusing is facilitated by the grease pencil marks on the slide.

The immediate result, in the case of a positive reaction, is a conspicuous increase in size of the pneumococci, due to conjugation of coccus and homologous antibody. Brownian movement is retarded, and the pneumococci become very apparent as lanceolate bodies, surrounded by a clear, highly refractive capsular zone. Agglutination soon follows, but is accelerated if the slide is warmed on the floor of the $37^{\circ} \mathrm{C}$. incubator for three to five minutes, and then again examined.

The end-result of the reaction is the aggregation of masses of agglutinated pneumococci and leucocytes; the pneumococci, sensitized by conjugation with the antibodies, are chemotactic to the phagocytes and polymorphs present in the peritoneal exudate. This characteristic reaction is seen only when virulent pneumococci are effective, belonging to the recognized serological types. The result, at times, may be a little obscured by the presence of undigested debris from the sputum, if exploration of the mouse's peritoneum is attempted too soon or the initial dose of sputum is too large. The rate at which the peritoneal cavity deals with this foreign material varies somewhat in different specimens of sputum.

The test may be carried out with equal facility at any interval exceeding three to four hours, which period, generally speaking, represents the minimum time required for sufficient multiplication of the virulent pneumococci injected and digestion of the sputum.

The agglutinating serums used have a titre of 1 in 40 , and are prepared by immunization of rabbits with representative type strains, isolated from recent cases of adult lobar pneumonia. The precaution of identifying both strains and serums by agglutination and absorption tests against the standard Rockefeller types has been observed always. Macroscopic agglutination has invariably confirmed the results of microscopic tests. The microscopic method is not only simpler and more rapid, but also considerably more delicate than the macroscopic, besides being economical of serum. The advantages are such that I now use this method alone.

I make no claim that the method described here is original ; the object of this communication is to make it widely known. The subject is reviewed by A. B. Sabin, ${ }^{2}$ to whom the credit is due of applying rapid methods of typing pneumococci. Sabin's procedure is very similar 